\title{
Assessment of Natural Radioactivity in Rivers Sediment and Soil from the Copper Belt Artisanal Mining Region, Democratic Republic of the Congo
}

\author{
Emmanuel K. Atibu1 ${ }^{*}$, João M. Oliveira², Margarida Malta², Marta Santos², Crispin K. Mulaji', \\ Pius T. Mpiana ${ }^{1}$, Fernando P. Carvalho ${ }^{2 *}$ \\ ${ }^{1}$ University of Kinshasa (UNIKIN), Faculty of Sciences, Department of Chemistry, Kinshasa, Democratic Republic of the Congo \\ ${ }^{2}$ Laboratório de Protecção e Segurança Radiologica, Instituto Superior Técnico/Campus Tecnológico Nuclear, \\ Universidadede Lisboa, Bobadela, Portugal \\ Email: *emmatibu@yahoo.fr, carvalho@ctn.tecnico.ulisboa.pt
}

How to cite this paper: Atibu, E. K., Oliveira, J. M., Malta, M., Santos, M., Mulaji, C. K., Mpiana, P. T., \& Carvalho, F. P. (2021). Assessment of Natural Radioactivity in Rivers Sediment and Soil from the Copper Belt Artisanal Mining Region, Democratic Republic of the Congo. Journal of Geoscience and Environment Protection, 9, 1-20.

https://doi.org/10.4236/gep.2021.97001

Received: April 26, 2021

Accepted: July 12, 2021

Published: July 15, 2021

Copyright (c) 2021 by author(s) and Scientific Research Publishing Inc. This work is licensed under the Creative Commons Attribution International License (CC BY 4.0).

http://creativecommons.org/licenses/by/4.0/

\begin{abstract}
The concentrations and distribution of naturally occurring radionuclides ${ }^{238} \mathrm{U}$, ${ }^{235} \mathrm{U},{ }^{234} \mathrm{U},{ }^{230} \mathrm{Th},{ }^{226} \mathrm{Ra},{ }^{210} \mathrm{~Pb},{ }^{232} \mathrm{Th},{ }^{228} \mathrm{Ra}$, and ${ }^{40} \mathrm{~K}$ ) were determined by alpha and gamma spectrometry in soil and sediments collected from Luilu and Dilala rivers located in the mining district of Kolwezi (Lualaba Province) of the Democratic Republic of the Congo. The average concentrations of ${ }^{238} \mathrm{U}$ and ${ }^{226} \mathrm{Ra}$ in the analyzed samples were 5 - 10 times higher than the world average values for soil provided by the United Nations Scientific Committee on the Effects of Atomic Radiation. However, the average concentrations of ${ }^{232} \mathrm{Th}$ were found similar to the world average. In both river basins, artisanal mining activities and mineral washing sites displayed the higher concentration values of radionuclides. The mean values of health risk indices calculated for those sites were found significantly higher compared to world average levels. Radiation protection measures seem needed to ensure the radiation safety of local populations.
\end{abstract}

\section{Graphical Abstract}

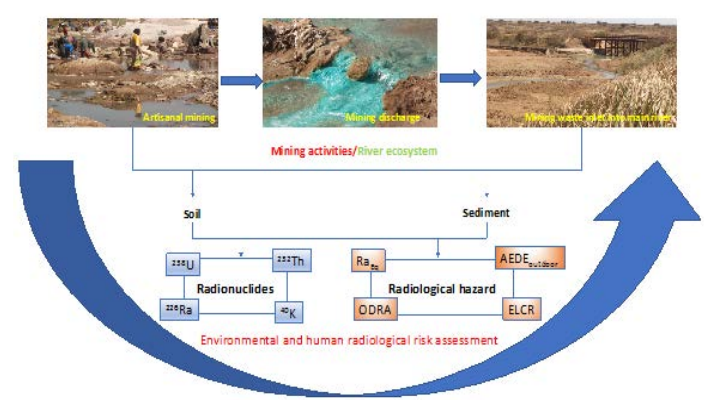




\section{Keywords}

Natural Radioactivity, Gamma-Ray Spectrometry, Alpha-Particle Spectrometry, Artisanal Mining Activity, Radiological Hazard

\section{Highlights}

- Natural radionuclides were investigated in soil and sediments collected along Luilu and Dilala rivers.

- $\alpha$-particle and $\gamma$-ray spectrometries revealed concentrations of ${ }^{238} \mathrm{U}$ and ${ }^{226} \mathrm{Ra}$ much higher than the worldwide average values for soil provided by UNSCEAR (2000).

- The highest concentrations of ${ }^{238} \mathrm{U},{ }^{235} \mathrm{U},{ }^{234} \mathrm{U},{ }^{230} \mathrm{Th},{ }^{210} \mathrm{~Pb}$ and ${ }^{226} \mathrm{Ra}$ corresponded to sites where artisanal mining and mineral washing activities were carried out.

- Assessment of radiological hazards for human population was performed through health risk indices.

- Mean values of ODRA, AEDE and ELCR were significantly higher in areas with artisanal mining activities in comparison with the world average levels

\section{Introduction}

Rocks and soil (the lithosphere) generally are the main reservoirs of primordial radioactive elements and sources to their transfer to other environmental compartments, such as the hydrosphere and biosphere (Eisenbud \& Gesell, 1997; Rahman \& Faheem, 2008). Human activities, such as industrial and artisanal mining, can enhance the concentration of naturally occurring radioelements in soil, particularly through the release of radionuclides with mining effluents, and thus potentially increasing the radiological hazards to the population. It is well known that the enhancement of environmental radioactivity levels may occur in mining and milling of radioactive ores for uranium production (Carvalho \& Oliveira, 2007; Carvalho et al., 2007) but may occur also in the exploitation of non-radioactive metals like iron, gold, copper, niobium, cobalt, and in the operation of quarries and sand pits (Michalik, 2017).

The former province of Katanga in the Democratic Republic of the Congo (DRC) is well known for its immense copper and cobalt deposits. In the East of the DRC, especially in the copper belt region (ex-Katanga province), mining activities were started during the colonial period by the "Union Minière du Katanga" owned by Belgium (Malaisse et al., 1994; Atibu et al., 2018; Atibu et al., 2016; Atibu et al., 2013). After the independence of the DRC in 1960, the national company "Gécamines" concentrated its mining activities in this province. Nowadays, many national and international companies implement mining projects in this region, alongside with artisanal mining activities (Atibu et al., 2018; Atibu et al., 2016; Atibu et al., 2013). The ex-Katanga region is known also for 
uranium and radium mining performed from 1921 to 1959 in the Shinkolobwe mine, located in the southern part of the copper belt, $119 \mathrm{~km}$ from Kolwezi. The Shinkolobwe underground uranium mine ceased operations and was sealed with concrete in 1960.

Many reports, from several regions around the globe like Egypt, Nigeria, Sudan, India, Iraq, give results on radionuclide measurements and radiological risks associated with mining and naturally occurring radionuclides in the environment (El-Sadek, 2005; Arogunjo et al., 2004; Khatir et al., 1998; Rajesh \& Kerur, 2018; Taqi et al., 2018; Papaefthymiou et al., 2007; Carvalho \& Oliveira, 2007). Unfortunately, the data for DRC on naturally occurring radionuclides in regions impacted by non-uranium mining is very scarce.

The Luilu and Dilala rivers cross several mining areas in the province of Lualaba and receive mining waste discharges. This region was selected as the study area because of the size of mining operations and value of the river system for local populations. The present work was aimed to determine the activity concentrations and distribution of key natural radionuclides $\left({ }^{238} \mathrm{U},{ }^{235} \mathrm{U},{ }^{234} \mathrm{U}\right.$, ${ }^{230} \mathrm{Th},{ }^{226} \mathrm{Ra},{ }^{210} \mathrm{~Pb},{ }^{232} \mathrm{Th},{ }^{228} \mathrm{Ra}$, and ${ }^{40} \mathrm{~K}$ ) along the basins of Luilu and Dilala rivers. Furthermore, results of analysis were used to assess the radiological risk to local populations through several radiological hazard parameters. These parameters include the Radium Equivalent Activity Index $\left(R a_{E q}\right)$, the Outdoor Gamma Absorbed Dose Rate (ODRA), the Annual Effective Dose Equivalent $\left(\mathrm{AEDE}_{\text {outdoor }}\right)$, the Excess Lifetime Cancer Risk (ELCR) and Hazard Indices $\left(H_{e x}\right.$ and $\left.H_{i n}\right)$. This is the first radiological risk assessment of this kind for the country.

\section{Materials and Methods}

\subsection{Description of the Study Area}

The district of Kolwezi, where the current study was performed, is located in the province of Lualaba (ex-Katanga region), at the southeastern side of the DRC, in Central Africa (Figure 1). The province of Lualaba is known as the richest region of DRC because of the large number of industrial and artisanal mining activities that significantly increased the national income over the last decades. The Kolwezi district, with an area of $213 \mathrm{~km}^{2}$ and about 453,000 inhabitants is located on the Manika plateau at the average altitude of $1500 \mathrm{~m}$ above the sea level. The stratigraphy and geology of this region, known as "Série des Mines" was investigated and described in detail by geologists (Grujensch, 1978). In the copper belt, there are sedimentary layers of clay-talc, and terrigenous layers with occasional elements of magmatic origin, and shales in which metal deposits occur,. Kolwezi holds today the largest and most important cobalt and copper mining centers of the DRC. Uranium deposits do exist in the region and uranium mining was also carried out in the ex-Katanga region up to 1960. The history of mining activities, together with the geological aspects of the district of Kolwezi, were previously described in several reports (Atibu et al., 2018; Atibu et al., 2016; Mees et al., 2013; Cheyns et al., 2014).

The co-occurrence of uranium with non-radioactive metals has been noticed 
and reported in some cases (Mustapha et al., 2007), but detailed analyses and assessment of the radiological impact was not made in this region. Besides mining companies, the riverine populations of the Kolwezi district undertake artisanal mining for copper and cobalt, which provides for family economies and supports mineral trade and other commercial activities in the country but contributes also to multiply the size of human population in contact with mining activities and potentially concerned with radiation exposure (Figure 2).

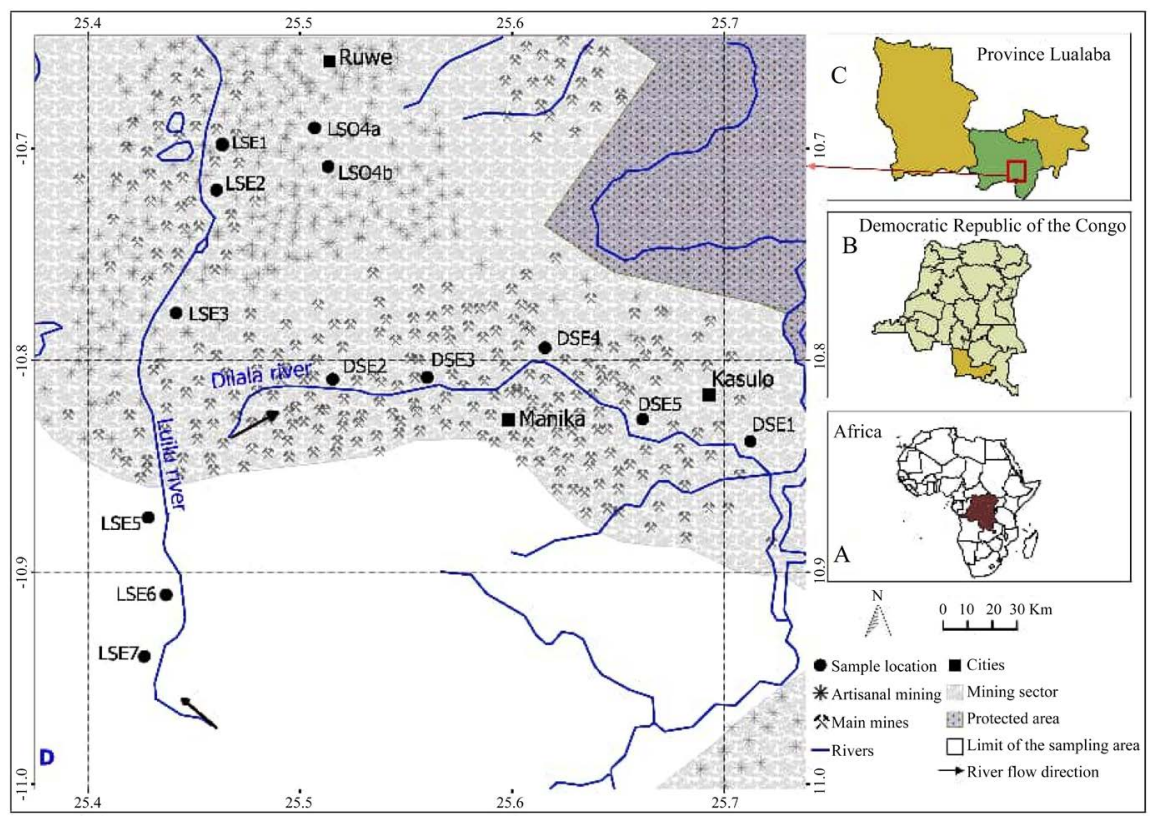

Figure 1. Map of the study area. A: Location of DRC in Africa. B: Map of Lualaba Province in DRC. C: Map of Kolwezi district in Lualaba Province. D: Sampling points along Luilu and Dilala rivers. Arrows indicate the directions of river flow.

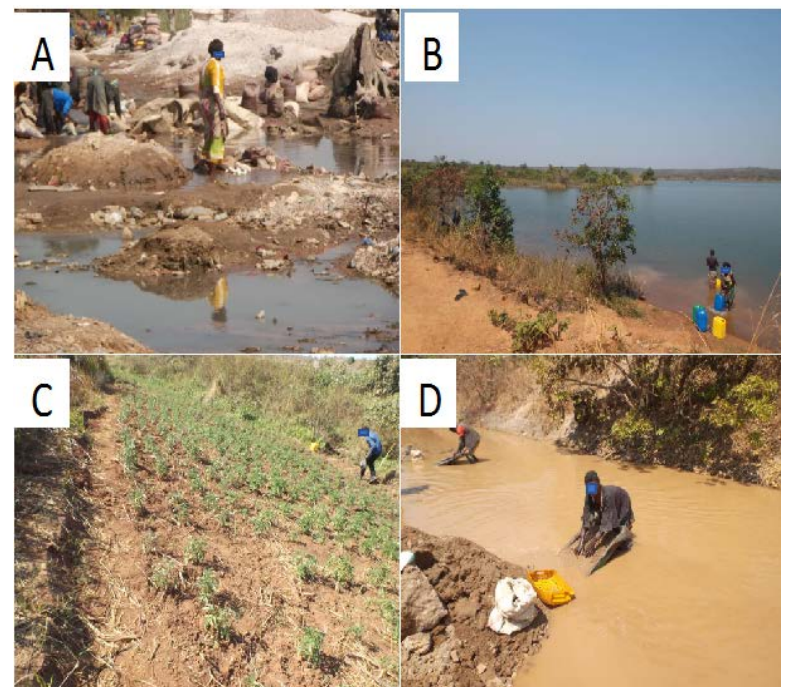

Figure 2. Human activities performed along Luilu and Dilala rivers. A: Artisanal mining in the Dilala river; B: Water collection for house activities on Luilu river; C: Cultivation of vegetables at Noah village, close to Luilu river; D: Minerals washing by artisanal miners (Photos by Emmanuel Atibu). 


\subsection{Collection of Environmental Samples}

Soil and sediment sampling was done in August 2017 and the analytical work in the laboratory was carried out in 2019. Sample identification, GPS coordinates of sampling sites, and human activities carried out at each area are reported in Table 1. Samples were collected from two river basins:

1) the Luilu river that flows through the mining and milling city of "Gécamines-Kapata" receiving effluents from such activities before merging into the Mpingiri river;

2) the Dilala River that separates the Kasulo city (on the left river bank) and the industrial zone, with a brewery, offices and truck garages and workshops for several mining companies located in the town of Manika (on the right river bank) (Figure 1).

Table 1. Sample labels, GPS coordinates in degrees, minutes, and seconds (and decimal degrees) and description of human activities performed in the banks of Dilala and Luilu rivers.

\begin{tabular}{|c|c|c|c|c|c|}
\hline Sampling site & Sample label & Latitude & Longitude & $\begin{array}{c}\text { Sample } \\
\text { characteristic }\end{array}$ & $\begin{array}{l}\text { Site description and activities performed } \\
\text { around the site }\end{array}$ \\
\hline \multirow{8}{*}{ Luilu river } & Lsed1 & $\begin{array}{c}\text { S } 10^{\circ} 40^{\prime} 272^{\prime \prime} \\
(-10.74222222)\end{array}$ & $\begin{array}{l}\mathrm{E} 025^{\circ} 22^{\prime} 195^{\prime \prime} \\
(25.420833333)\end{array}$ & Sediment & $\begin{array}{l}\text { Sludge and sediment collection from the } \\
\text { riverbed by artisanal miners. }\end{array}$ \\
\hline & Lsed2 & $\begin{array}{c}\text { S } 10^{\circ} 40^{\prime} 120^{\prime \prime} \\
(-10.70000000)\end{array}$ & $\begin{array}{l}\mathrm{E} 025^{\circ} 22^{\prime} 028^{\prime \prime} \\
(25.374444444)\end{array}$ & Sediment & Existence of a metal dike \\
\hline & Lsed3 & $\begin{array}{c}\mathrm{S} 10^{\circ} 40^{\prime} 455^{\prime \prime} \\
(-10.79305555)\end{array}$ & $\begin{array}{l}\text { E } 025^{\circ} 21^{\prime} 538^{\prime \prime} \\
(25.499444444)\end{array}$ & Sediment & No human activity performed \\
\hline & Lsol4a & $\begin{array}{c}\mathrm{S} 10^{\circ} 40^{\prime} 131^{\prime \prime} \\
(-10.70305555)\end{array}$ & $\begin{array}{l}\text { E } 025^{\circ} 21^{\prime} 556^{\prime \prime} \\
(25.504444444)\end{array}$ & Soil & $\begin{array}{l}\text { Noah village garden: cultivation of tomato, } \\
\text { cabbage and corn in rainy season }\end{array}$ \\
\hline & Lsol4b & $\begin{array}{c}\mathrm{S} 10^{\circ} 40^{\prime} 131^{\prime \prime} \\
(-10.70305555)\end{array}$ & $\begin{array}{l}\text { E } 025^{\circ} 21^{\prime} 556^{\prime \prime} \\
(25.504444444)\end{array}$ & Soil & $\begin{array}{l}\text { Noah village garden: cultivation of tomato, } \\
\text { cabbage and corn in rainyseason }\end{array}$ \\
\hline & Lsed5 & $\begin{array}{c}\text { S } 10^{\circ} 46^{\prime} 715^{\prime \prime} \\
(-10.96527777)\end{array}$ & $\begin{array}{l}\text { E } 025^{\circ} 22^{\prime} 041^{\prime \prime} \\
(25.378055555)\end{array}$ & Sediment & No human activity performed \\
\hline & Lsed6 & $\begin{array}{c}\mathrm{S} 10^{\circ} 46^{\prime} 233^{\prime \prime} \\
(-10.83138888)\end{array}$ & $\begin{array}{l}\text { E } 025^{\circ} 21^{\prime} 738^{\prime \prime} \\
(25.555000000)\end{array}$ & Sediment & Fishing and laundry \\
\hline & Lsed7 & $\begin{array}{c}\text { S } 10^{\circ} 45^{\prime} 927^{\prime \prime} \\
(-11.00750000)\end{array}$ & $\begin{array}{l}\text { E } 025^{\circ} 21^{\prime} 165^{\prime \prime} \\
(25.395833333)\end{array}$ & Sediment & Fishing \\
\hline \multirow{5}{*}{ Dilala river } & Dsed1 & $\begin{array}{c}\mathrm{S} 10^{\circ} 42^{\prime} 504^{\prime \prime} \\
(-10.91000000)\end{array}$ & $\begin{array}{l}\text { E } 025^{\circ} 28^{\prime} 999^{\prime \prime} \\
(25.744166666)\end{array}$ & Sediment & Clothes and minerals washing \\
\hline & Dsed2 & $\begin{array}{c}\mathrm{S} 10^{\circ} 42^{\prime} 543^{\prime \prime} \\
(-10.85083333)\end{array}$ & $\begin{array}{c}\text { E } 025^{\circ} 29^{\prime} 094^{\prime \prime} \\
(25.509444444)\end{array}$ & Sediment & Minerals washing \\
\hline & Dsed3 & $\begin{array}{c}\mathrm{S} 10^{\circ} 42^{\prime} 523^{\prime \prime} \\
(-10.84527777)\end{array}$ & $\begin{array}{l}\text { E } 025^{\circ} 29^{\prime} 184^{\prime \prime} \\
(25.534444444)\end{array}$ & Sediment & Minerals washing \\
\hline & Dsed4 & $\begin{array}{c}\mathrm{S} 10^{\circ} 42^{\prime} 426^{\prime \prime} \\
(-10.81833333)\end{array}$ & $\begin{array}{c}\text { E } 025^{\circ} 29^{\prime} 409^{\prime \prime} \\
(25.596944444)\end{array}$ & Sediment & Minerals washing \\
\hline & Dsed5 & $\begin{array}{c}\text { S } 10^{\circ} 42^{\prime} 440^{\prime \prime} \\
(-10.82222222)\end{array}$ & $\begin{array}{c}\text { E } 025^{\circ} 29^{\prime} 727^{\prime \prime} \\
(25.685277777)\end{array}$ & Sediment & Clothes washing \\
\hline
\end{tabular}


About 150 - $250 \mathrm{~g}$ of soil samples from near surface (0 - $20 \mathrm{~cm}$ deep) layers were collected with a shovel on riverbanks. The area represents agricultural land irrigated with river water and used by population for agriculture and as a ground for human settlements. The river sediments surface layer of (0 - $5 \mathrm{~cm}$ depth) were manually collected from the riverbed at a distance of about $1-2 \mathrm{~m}$ from the shore and at $10-30 \mathrm{~cm}$ water depth. The population is in daily close contact with sediments and soil because of their mining activities and the use of river sediments (clay) in house construction. Therefore, for the purpose of radiological hazard assessment the soil and sediments were considered together as they are main sources of ambient radiation (Figure 2).

\subsection{Sample Pretreatment}

Soil and sediment samples were oven dried at $80^{\circ} \mathrm{C}-100^{\circ} \mathrm{C}$ during $24 \mathrm{~h}$, disaggregated and sieved through a $63 \mu \mathrm{m}$ stainless steel sieve to remove coarse sand, stones, pebbles and other macro-impurities that with their large volume and mass and low radionuclide content would modify radionuclide activity concentrations $\left(\mathrm{Bq} \cdot \mathrm{kg}^{-1}\right)$ if not eliminated.

Less than $63 \mu \mathrm{m}$ grain-size fraction, the largest fraction of the sample $(>4 / 5)$ and containing most radioactivity, was used for radionuclide analysis in order to allow the comparison between samples (Carvalho et al., 2007; Carvalho, 1995).

\subsection{Sample Analysis by Gamma-Ray Spectrometry}

After sample homogenization, aliquots of the less than $63 \mu \mathrm{m}$ grain-size fraction from soil and sediment samples were placed in Petri dishes and compacted to completely fill the container (no head space was left), and hermetically sealed using cellophane tape. Once in the containers, the samples were kept aside for about one month in order to ensure the formation of secular radioactive equilibrium between ${ }^{226} \mathrm{Ra}$ and its radioactive decay products ${ }^{214} \mathrm{~Pb}$ and ${ }^{214} \mathrm{Bi}$. Afterwards, they were analyzed by gamma-ray spectrometry for the determination of activity concentrations of radionuclides ${ }^{40} \mathrm{~K},{ }^{226} \mathrm{Ra},{ }^{228} \mathrm{Ra}$ in the samples. The acquisition time was set to $15 \mathrm{~h}$ and the photo peaks used for the activity determination were $1460.82 \mathrm{keV}$ for ${ }^{40} \mathrm{~K} ; 295.2,351.9$ and $609.3 \mathrm{keV}$ for ${ }^{226} \mathrm{Ra}$, and $238.63,583.19$ and $911.20 \mathrm{keV}$ for ${ }^{228} \mathrm{Ra}$.

A 50\% relative efficiency broad energy HPGe detector (Canberra BEGe model BE5030), with an active volume of $150 \mathrm{~cm}^{3}$ and a carbon window was used for the gamma spectrometry measurements. A thick lead shield with internal lining of copper and tin protects the detector from the environmental radiation background. Standard nuclear electronics was used for signal treatment and the software Genie 2000 (version 3.4) was employed for the spectrometric data acquisition and spectral analysis. The detection efficiency was determined using NIST-traceable multi-gamma radioactive standards (POLATOM Laboratory of Radioactivity Standards) with an energy range from 46.5 to $1836 \mathrm{keV}$, and customized in a water-equivalent epoxy resin matrix (density of $1.15 \mathrm{~g} \cdot \mathrm{cm}^{-3}$ ) to ex- 
actly reproduce the geometries of the samples in the sample containers used. GESPECOR software (version 4.2) was used to correct for matrix (self-attenuation) and coincidence summing effects. The stability of the system (activity, FWHM, centroid) was checked at least once a week with a ${ }^{152} \mathrm{Eu}$ certified point source. Results for radionuclide activity concentrations are expressed in Bq. $\mathrm{kg}^{-1}$ (dry weight), with the expanded uncertainty $(\mathrm{k}=2)$.

External Quality Control was assured through the participation in frequent intercomparison exercises organized by international organizations, such as the International Atomic Energy Agency (IAEA), with consistent good results (Povinec et al., 2007; Pham et al., 2014; Pham et al., 2016). This laboratory technique is accredited according to the ISO/IEC 17025:2005 standards.

\subsection{Sample Analysis by Alpha Spectrometry}

Aliquots of the homogenized $<63 \mu \mathrm{m}$ fraction of samples were used for the determination of ${ }^{238} \mathrm{U},{ }^{235} \mathrm{U},{ }^{234} \mathrm{U},{ }^{232} \mathrm{Th},{ }^{230} \mathrm{Th}$, and ${ }^{210} \mathrm{~Pb}$. Among these radionuclides, ${ }^{210} \mathrm{~Pb}$ was calculated through the determination of the alpha emitter ${ }^{210} \mathrm{Po}$ in secular radioactive equilibrium with ${ }^{210} \mathrm{~Pb}$, ensured with the sample storage for about 2 years. These radionuclides were determined in all samples applying a sequential radiochemical separation of radioelements, followed by their electrodeposition on metal planchets. Thereafter, radiation measurement was carried out by alpha spectrometry using an OCTETEplus spectrometer from ORTEC, with $450 \mathrm{~mm}^{2}$ active surface ULTRA AS Mark detectors. The Maestro software from ORTEC was used in spectrum analysis. The procedures followed, including analytical quality control, are described in detail and validated in published reports (Carvalho \& Oliveira, 2007; Oliveira \& Carvalho, 2006; Carvalho \& Oliveira, 2009). Quality control was ensured through periodic participation in IAEA intercomparison exercises with consistent good results over the years, as referred previously (Povinec et al., 2007; Pham et al., 2014; Pham et al., 2016). Results for radionuclide activity concentration are expressed in $\mathrm{Bq} \cdot \mathrm{kg}^{-1}$ (dry weight), with the expanded uncertainty $(\mathrm{k}=2)$.

\subsection{Evaluation of Radiological Hazard and Health Effects}

To estimate the radiation risks for human population from exposure to radionuclides in soil and sediments, several radiological indices were calculated such as, the Radium Equivalent Activity Index $\left(R a_{E q}\right)$, the Outdoor Gamma Absorbed Dose Rate (ODRA), the Annual Effective Dose Equivalent ( $\left.\mathrm{AEDE}_{\text {outdor }}\right)$, the Excess Lifetime Cancer Risk (ELCR) and Hazard indices $\left(H_{e x}\right.$ and $\left.H_{i n}\right)$. These indices are defined as follows.

\subsubsection{Radium Equivalent Activity Index $\left(R a_{E q}\right)$}

Defined by Beretka and Mathew (1985), the Radium Equivalent Activity Index $\left(R a_{E q}\right)$ allows a single number to describe the gamma output and the radiation hazards associated with different mixtures of ${ }^{238} \mathrm{U},{ }^{232} \mathrm{Th}$ and ${ }^{40} \mathrm{~K}$ in samples. It was estimated using a well-established relation (Taqi et al., 2018; UNSCEAR, 
2000):

$$
R a_{E q}\left(\mathrm{~Bq} \cdot \mathrm{kg}^{-1}\right)=A_{R a}+1.43 A_{T h}+0.077 A_{K}
$$

where $A_{R a}, A_{T h}$ and $A_{K}$ are the activity concentration in $\mathrm{Bq} \cdot \mathrm{kg}^{-1}$ of ${ }^{226} \mathrm{Ra},{ }^{232} \mathrm{Th}$ and ${ }^{40} \mathrm{~K}$ respectively in soil. It is assumed that $370 \mathrm{~Bq} \cdot \mathrm{kg}^{-1}$ of ${ }^{226} \mathrm{Ra}, 259 \mathrm{~Bq} \cdot \mathrm{kg}^{-1}$ of ${ }^{232} \mathrm{Th}$ and $4810 \mathrm{~Bq} \cdot \mathrm{kg}^{-1}$ of ${ }^{40} \mathrm{~K}$ produce the same gamma ray dose rate (UNSCEAR, 2000). The world average of $R a_{E q}$ in soil is $370 \mathrm{~Bq} \cdot \mathrm{kg}^{-1}$ (UNSCEAR, 2000).

\subsubsection{Outdoor Gamma Absorbed Dose Rate (ODRA)}

The first major step for evaluating the health risk from radiation exposure is the calculation of absorbed dose rate. Concerning biological effects, the radiological and clinical effects are directly linked to the absorbed dose rate (Fisher \& Fahey, 2017). The outdoor gamma absorbed dose rate (ODRA) due to environmental gamma radiation in the air, at $1 \mathrm{~m}$ above the ground surface and for a uniform distribution of the naturally occurring radionuclides ${ }^{238} \mathrm{U},{ }^{232} \mathrm{Th}$ and ${ }^{40} \mathrm{~K}$ in the soil, was calculated using the guidelines provided by UNSCEAR (UNSCEAR, 2000). The factors used to convert activity concentrations of ${ }^{238} \mathrm{U},{ }^{232} \mathrm{Th}$ and ${ }^{40} \mathrm{~K}$ into dose rate are $0.462 \mathrm{nGy} \cdot \mathrm{h}^{-1}, 0.604 \mathrm{nGy} \cdot \mathrm{h}^{-1}$ and $0.042 \mathrm{nGy} \cdot \mathrm{h}^{-1}$, respectively. Therefore, the index ODRA can be calculated as follows:

$$
\operatorname{ODRA}\left(\mathrm{nGy} \cdot \mathrm{h}^{-1}\right)=0.462 A_{U}+0.604 A_{T h}+0.0417 A_{K}
$$

where $A_{U}, A_{T h}$ and $A_{K}$ are the activity concentration in Bq.kg ${ }^{-1}$ of ${ }^{238} \mathrm{U}^{232} \mathrm{Th}$ and ${ }^{40} \mathrm{~K}$ respectively in soil. The world average ODRA value is $59 \mathrm{nGy} \cdot \mathrm{h}^{-1}$ and the world range of ODRA is 18 - $93 \mathrm{nGy} \cdot \mathrm{h}^{-1}$ (UNSCEAR, 2000; UNSCEAR, 2010).

\subsubsection{Annual Effective Dose Equivalent (AEDE)}

The Annual Effective Dose Equivalent (AEDE) received by a person living in the area, was calculated using the following equation:

$$
\mathrm{AEDE}=\mathrm{ODRA} \times \mathrm{DCF} \times \mathrm{OF} \times \mathrm{T}
$$

where DCF is the dose conversion factor $\left(0.7 \mathrm{~Sv} \cdot \mathrm{Gy}^{-1}\right)$. The DCF is used to convert the absorbed dose rate to the human effective dose equivalent with an outdoor occupancy factor (OF) of 20\% (UNSCEAR, 1993) and $\mathrm{T}$ is the exposure time $\left(8760 \mathrm{~h} \cdot \mathrm{y}^{-1}\right)($ UNSCEAR, 2000). So the AEDE can be calculated using the following equation:

$$
\begin{aligned}
& \operatorname{AEDE}_{\text {outdoor }}\left(\mathrm{mSv} \cdot \mathrm{y}^{-1}\right) \\
& =\operatorname{ODRA}\left(\mathrm{nGy} \cdot \mathrm{h}^{-1}\right) \times 0.7 \mathrm{~Sv} \cdot \mathrm{Gy}^{-1} \times 0.2 \times 8760\left(\mathrm{~h} \cdot \mathrm{y}^{-1}\right) \times 10^{-6}
\end{aligned}
$$

The world average value of AEDE is $0.07 \mathrm{mSv} \cdot \mathrm{y}^{-1}$ (UNSCEAR, 2000; UNSCEAR, 2010).

\subsubsection{Excess Lifetime Cancer Risk (ELCR)}

The Excess Lifetime Cancer Risk (ELCR) estimates the probability of cancer incidence in members of a human population for a specific lifetime, due to expo- 
sure to the naturally occurring radionuclides. The ELCR was calculated using the equation:

$$
\mathrm{ELCR}=\mathrm{AEDE} \times \mathrm{DL} \times \mathrm{RF}
$$

where DL is the duration of life (assumed as 70 years), and RF is the risk factor of contracting a fatal cancer per sievert $\left(\mathrm{Sv}^{-1}\right)$ received. For stochastic effects, the ICRP 60 recommends the use of $\mathrm{RF}=0.05$ for the members of the public (ICRP, 1991; Taskin et al., 2009). The world average value of ELCR is 0.00029 (UNSCEAR, 2000; UNSCEAR, 2010).

\subsubsection{Hazard Indices}

To make an assessment of the health effects from the internal and external exposure to radioactivity from earth's surface materials containing ${ }^{238} \mathrm{U},{ }^{232} \mathrm{Th}$ and ${ }^{40} \mathrm{~K}$, Beretka and Mathew (1985) defined two indices which objective is to compare the radiation dose received to a dose equivalent limit of $1 \mathrm{mSv} \cdot \mathrm{y}^{-1}$ recommended for members of the public (ICRP, 1991). The external hazard index $\left(H_{e x}\right)$ is defined as:

$$
H_{e x}=\left(\frac{A_{U}}{370 \mathrm{~Bq} \cdot \mathrm{kg}^{-1}}+\frac{A_{T h}}{259 \mathrm{~Bq} \cdot \mathrm{kg}^{-1}}+\frac{A_{K}}{4810 \mathrm{~Bq} \cdot \mathrm{kg}^{-1}}\right)
$$

where $A_{U}, A_{T h}$ and $A_{K}$ are the activity concentrations in Bq. $\mathrm{kg}^{-1}$ of ${ }^{238} \mathrm{U},{ }^{232} \mathrm{Th}$ and ${ }^{40} \mathrm{~K}$, respectively (Suresh Ghandhi et al., 2014). The $H_{e x}$ value must not exceed the unity $\left(H_{e x} \leq 1\right)$ for the radiation hazard to be accepted as negligible.

On the other hand, the internal hazard index $\left(H_{\text {in }}\right)$ estimates the internal exposure to atmospheric radon and its short-lived products, which are inhalable and hazardous (carcinogenic) to the respiratory system. It is calculated through the equation:

$$
H_{\text {in }}=\left(\frac{A_{R a}}{185 \mathrm{~Bq} \cdot \mathrm{kg}^{-1}}+\frac{A_{T h}}{259 \mathrm{~Bq} \cdot \mathrm{kg}^{-1}}+\frac{A_{K}}{4810 \mathrm{~Bq} \cdot \mathrm{kg}^{-1}}\right)
$$

where $A_{R a}, A_{T h}$ and $A_{K}$ are the soil activity concentrations in $\mathrm{Bq} \cdot \mathrm{kg}^{-1}$ of ${ }^{226} \mathrm{Ra}$, ${ }^{232} \mathrm{Th}$ and ${ }^{40} \mathrm{~K}$ respectively (Taqi et al., 2018; Agbalagba \& Onoja, 2011). The $H_{\text {in }}$ value must not exceed 1 to be accepted as negligible.

\subsection{Data Analysis}

Statistical treatment of data, using Spearman's rank order correlation, was made using SigmaStat 12.5 (Systat Software, Inc., USA).

\section{Results and Discussion}

\subsection{Radionuclide Concentrations in Samples}

The activity concentrations of primordial radionuclides ${ }^{238} \mathrm{U},{ }^{235} \mathrm{U},{ }^{232} \mathrm{Th}$ and ${ }^{40} \mathrm{~K}$ ), several ${ }^{238} \mathrm{U}$ daughters ${ }^{234} \mathrm{U},{ }^{230} \mathrm{Th},{ }^{226} \mathrm{Ra}$ and ${ }^{210} \mathrm{~Pb}$ ) and the ${ }^{232} \mathrm{Th}$ daughter ${ }^{228} \mathrm{Ra}$, are given in Table 2, in Bq. $\mathrm{kg}^{-1}$ of dry weight, for each one of samples collected.

The highest values recorded in this study were $973 \pm 29 \mathrm{~Bq} \cdot \mathrm{kg}^{-1}$ for ${ }^{238} \mathrm{U}, 54 \pm$ 
$3 \mathrm{~Bq} \cdot \mathrm{kg}^{-1}$ for ${ }^{232} \mathrm{Th}, 363 \pm 31 \mathrm{~Bq} \cdot \mathrm{kg}^{-1}$ for ${ }^{40} \mathrm{~K}$, and $330 \pm 34 \mathrm{~Bq} \cdot \mathrm{kg}^{-1}$ for ${ }^{226} \mathrm{Ra}$ and correspond to the sampling sites Dsed4, Lsed6, Lsed7 and Lsed1, respectively. Figure 3 shows in a glance the variation of activity concentrations at sampling sites along both rivers. Probability plots of data showed that these concentration values generally follow a normal distribution thus demonstrating data cohesiveness, although with some outliers (not shown).

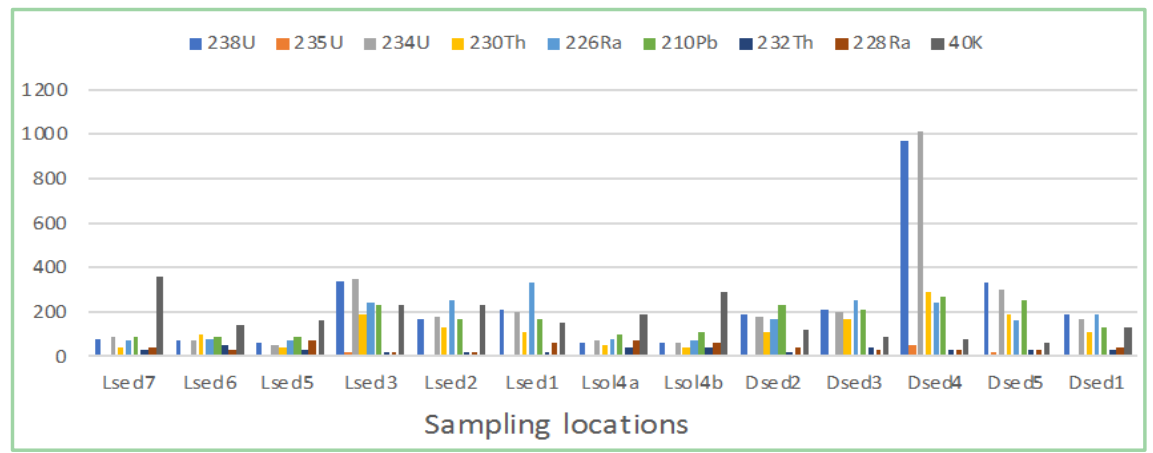

Figure 3. Variation of activity concentration of radionuclides $\left(\mathrm{Bq} \cdot \mathrm{kg}^{-1}\right)$ with sampling sites: L for Luilu river basin; D for Dilala river basin. Sampling locations from left to right correspond to the most upstream to downstream.

Table 2. Activity concentrations $\left(\mathrm{Bq} \cdot \mathrm{kg}^{-1} \pm 2 \sigma\right)$ of naturally occurring radionuclides in selected soil and sediment samples from Luilu and Dilala river basins.

\begin{tabular}{|c|c|c|c|c|c|c|c|c|c|c|}
\hline River Name & Sample label & ${ }^{238} \mathrm{U}$ & ${ }^{235} \mathrm{U}$ & ${ }^{234} \mathrm{U}$ & ${ }^{230} \mathrm{Th}$ & ${ }^{226} \mathrm{Ra}$ & ${ }^{210} \mathrm{~Pb}$ & ${ }^{232} \mathrm{Th}$ & ${ }^{228} \mathrm{Ra}$ & ${ }^{40} \mathrm{~K}$ \\
\hline \multirow{10}{*}{ Luilu river } & Lsed7 & $79 \pm 3$ & $4.8 \pm 0.4$ & $87 \pm 3$ & $36 \pm 2$ & $74 \pm 4$ & $88 \pm 6$ & $25 \pm 2$ & $42.4 \pm 4.9$ & $363 \pm 31$ \\
\hline & Lsed6 & $72 \pm 3$ & $3.4 \pm 0.4$ & $66 \pm 3$ & $104 \pm 6$ & $80 \pm 6$ & $88 \pm 6$ & $54 \pm 3$ & $30.8 \pm 6.0$ & $136 \pm 30$ \\
\hline & Lsed5 & $57 \pm 2$ & $2.7 \pm 0.4$ & $47 \pm 2$ & $40 \pm 2$ & $68 \pm 4$ & $89 \pm 6$ & $28 \pm 2$ & $67.0 \pm 10.0$ & $161 \pm 42$ \\
\hline & Lsed3 & $337 \pm 13$ & $17.0 \pm 2.0$ & $351 \pm 13$ & $191 \pm 14$ & $236 \pm 21$ & $233 \pm 19$ & $16 \pm 2$ & $20.0 \pm 2.4$ & $225 \pm 19$ \\
\hline & Lsed2 & $171 \pm 7$ & $10.0 \pm 1.0$ & $178 \pm 7$ & $133 \pm 10$ & $245 \pm 18$ & $171 \pm 14$ & $19 \pm 2$ & $23.0 \pm 3.3$ & $227 \pm 19$ \\
\hline & Lsed1 & $207 \pm 10$ & $8.0 \pm 1.0$ & $201 \pm 10$ & $108 \pm 8$ & $330 \pm 34$ & $166 \pm 13$ & $24 \pm 2$ & $64.0 \pm 11.0$ & $154 \pm 49$ \\
\hline & Average \pm SD & $154 \pm 6$ & $7.6 \pm 0.9$ & $155 \pm 6$ & $102 \pm 7$ & $172 \pm 14$ & $139 \pm 11$ & $28 \pm 2$ & $41 \pm 6$ & $211 \pm 76$ \\
\hline & Lsol4a & $59 \pm 3$ & $3.4 \pm 0.6$ & $66 \pm 3$ & $46 \pm 12$ & $84 \pm 6$ & $98 \pm 7$ & $42 \pm 11$ & $72.0 \pm 12.0$ & $189 \pm 62$ \\
\hline & Lsol4b & $63 \pm 3$ & $2.1 \pm 0.5$ & $59 \pm 2$ & $39 \pm 3$ & $71 \pm 5$ & $107 \pm 6$ & $44 \pm 3$ & $55.9 \pm 8.4$ & $291 \pm 41$ \\
\hline & Average \pm SD & $61 \pm 3$ & $2.8 \pm 0.6$ & $62 \pm 3$ & $42 \pm 8$ & $78 \pm 6$ & $102 \pm 7$ & $43 \pm 7$ & $64 \pm 10$ & $240 \pm 52$ \\
\hline \multirow{6}{*}{ Dilala river } & Dsed2 & $189 \pm 8$ & $9.3 \pm 0.8$ & $180 \pm 8$ & $105 \pm 16$ & $171 \pm 11$ & $234 \pm 19$ & $23 \pm 6$ & $34.9 \pm 3.5$ & $117 \pm 12$ \\
\hline & Dsed3 & $207 \pm 7$ & $11.1 \pm 0.8$ & $197 \pm 7$ & $165 \pm 42$ & $247 \pm 62$ & $211 \pm 17$ & $35 \pm 11$ & $33.3 \pm 3.9$ & $93 \pm 12$ \\
\hline & Dsed4 & $973 \pm 29$ & $46.0 \pm 2.0$ & $1013 \pm 30$ & $285 \pm 16$ & $242 \pm 32$ & $271 \pm 20$ & $33 \pm 2$ & $29.8 \pm 3.8$ & $76 \pm 13$ \\
\hline & Dsed5 & $333 \pm 14$ & $15.0 \pm 2.0$ & $302 \pm 13$ & $185 \pm 21$ & $158 \pm 19$ & $246 \pm 19$ & $30 \pm 4$ & $31.6 \pm 4.9$ & $62 \pm 13$ \\
\hline & Dsed1 & $188 \pm 6$ & $8.7 \pm 0.8$ & $170 \pm 6$ & $110 \pm 20$ & $193 \pm 13$ & $131 \pm 10$ & $28 \pm 7$ & $37.1 \pm 3.6$ & $129 \pm 13$ \\
\hline & Average \pm SD & $378 \pm 13$ & $18 \pm 1$ & $372 \pm 13$ & $170 \pm 23$ & $202 \pm 27$ & $219 \pm 17$ & $29.8 \pm 6.0$ & $33 \pm 4$ & $95 \pm 13$ \\
\hline Worldwide soil [22] & Average & 35 & & & & 35 & & 30 & & 400 \\
\hline
\end{tabular}


Sediments from the Luilu river basin showed an increasing trend in concentrations of uranium $\left({ }^{238} \mathrm{U}\right)$ from Lsed7 to Lsed1, i.e., going downstream, indicating uranium rich geologic deposits in the lower catchment, while for thorium $\left({ }^{232} \mathrm{Th}\right)$ no concentration trend was observed. With ${ }^{40} \mathrm{~K}$, when compared with uranium, the opposite trend was observed, i.e., higher concentrations in the upper catchment of the river and decreasing downstream, thus suggesting that rocks in the upper zone of the river basin are a different geologic formation, probably potassium rich magmatic rocks (Grujensch, 1978). In the Dilala river sediments, there were no regular trends in uranium series along the river path, but sediments at station Dsed4 showed a clear occurrence of elevated uranium concentrations, while ${ }^{232} \mathrm{Th}$ and ${ }^{40} \mathrm{~K}$ concentrations showed no geographic trend. Agricultural soil samples from the Luilu river basin displayed slightly lower uranium and uranium daughter concentrations, but similar concentrations for other radionuclides when compared to river sediments (Table 2).

The wide difference of average radionuclide concentrations between the two river basins can be explained by the different geology of the basins, and likely also by physical, chemical and geo-chemical parameters acting at specific sampling sites (Issa et al., 2013; Ramasamy et al., 2011). It is noteworthy that sediments from Luilu River basin globally displayed much lower concentrations of ${ }^{238} \mathrm{U}$ and ${ }^{234} \mathrm{U}$ isotopes (uranium series) than those from the Dilala River basin, although both have similar concentrations of ${ }^{232} \mathrm{Th}$ (thorium series) (Table 2). The Dilala River basin is therefore richer in uranium minerals and, actually, the ${ }^{238} \mathrm{U}$ concentration at Dsed4, $973 \pm 29 \mathrm{~Bq} \cdot \mathrm{kg}^{-1}$, as well as the accompanying ${ }^{234} \mathrm{U}$ concentration, are much higher than in all other samples. The ${ }^{238} \mathrm{U}$ activity concentration at Dsed4 corresponds to a mass concentration of uranium of $79 \pm 2.4$ $\mathrm{mg} \cdot \mathrm{kg}^{-1}$, much higher than the average uranium concentration of $3 \mathrm{mg} \cdot \mathrm{kg}^{-1}$ in the earth crust, and similar to concentrations commonly found in uranium bearing regions only (Choppin et al., 1995). Interestingly, for ${ }^{40} \mathrm{~K}$ the samples from river basins show the opposite ranking when compared to uranium, with the terrains of Luilu River much richer in potassium than those from Dilala River (Table 2), thus reinforcing the idea of river basins with different geological settings. Figure 4 highlights these differences between river basins through the graphic plot of radionuclide ratios using ${ }^{232} \mathrm{Th}$ for normalization: while in Luilu basin high ${ }^{40} \mathrm{~K}$ concentrations are associated with high ${ }^{238} \mathrm{U}$ concentrations, in the Dilala basin high ${ }^{40} \mathrm{~K}$ is associated with low ${ }^{238} \mathrm{U}$ concentrations (Table 3).

Compared with the world average values given by the UNSCEAR (2000), the average concentrations of ${ }^{238} \mathrm{U}$ and ${ }^{226} \mathrm{Ra}$ in sediments samples from Luilu and Dilala rivers are 5 - 10 times higher than worldwide averages, while the average ${ }^{232} \mathrm{Th}$ in sediments from both rivers are similar to the world ${ }^{232} \mathrm{Th}$ average value (Table 2). However, the sampling sites Dsed4 and Lsed1 where artisanal mining and mineral washing is performed, displayed very high concentration values for ${ }^{238} \mathrm{U},{ }^{235} \mathrm{U},{ }^{234} \mathrm{U},{ }^{230} \mathrm{Th},{ }^{210} \mathrm{~Pb}$ and ${ }^{226} \mathrm{Ra}$ respectively. This suggests that there is natural occurrence of hot spots but also artisanal mining activities can enhance the activity concentration of radionuclides in soil and sediments. 

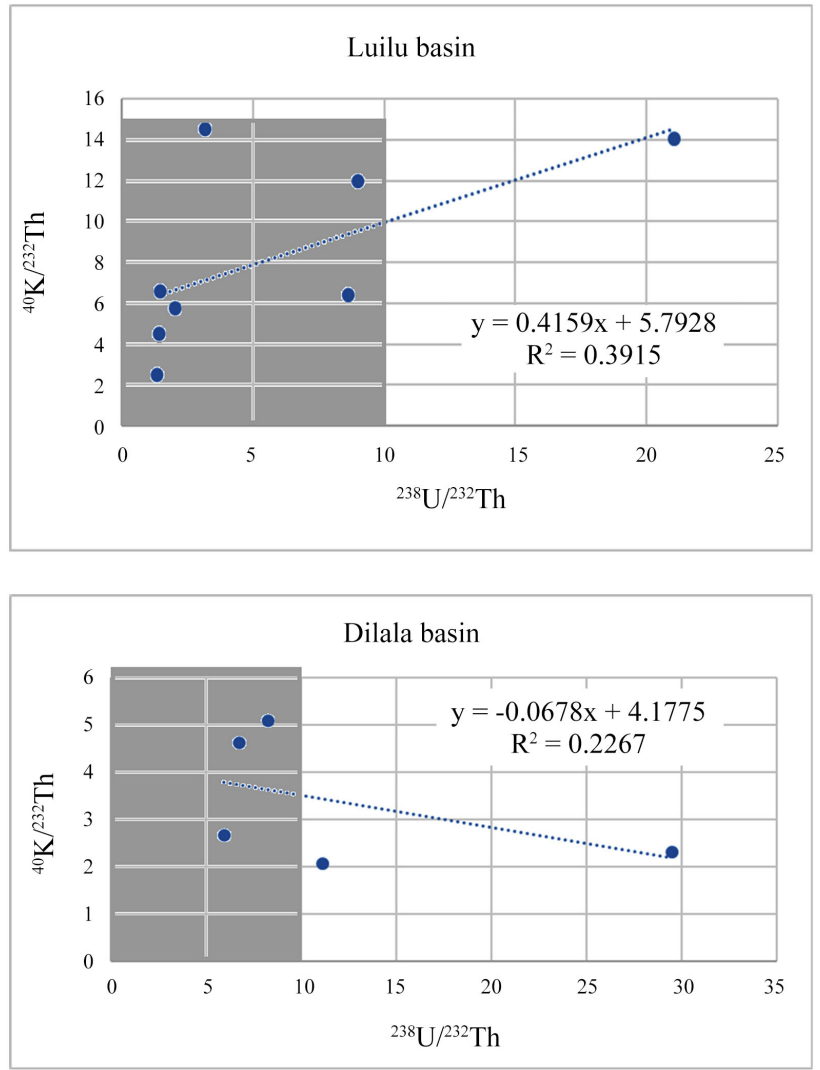

Figure 4. Activity concentration ratios for sediments and soil from the two river basins in RDC. Natural radioactivity background are the shaded areas. Points outside are either natural hotspots or areas contaminated by anthropogenic activities.

Table 3. Activity concentration ratios for several radionuclides.

\begin{tabular}{cccccccc}
\hline Sample & \multicolumn{5}{c}{ Within uranium series } & \multicolumn{5}{c}{ Between primordial radionuclides } \\
\cline { 2 - 8 } label & ${ }^{234} \mathrm{U} /{ }^{238} \mathrm{U}$ & ${ }^{230} \mathrm{Th} /{ }^{238} \mathrm{U}$ & ${ }^{226} \mathrm{Ra} /{ }^{238} \mathrm{U}$ & ${ }^{210} \mathrm{~Pb} /{ }^{238} \mathrm{U}$ & ${ }^{238} \mathrm{U} /{ }^{40} \mathrm{~K}$ & ${ }^{238} \mathrm{U} /{ }^{232} \mathrm{Th}$ & ${ }^{40} \mathrm{~K} /{ }^{232} \mathrm{Th}$ \\
\hline Lsed7 & 1.1 & 0.5 & 0.9 & 1.1 & 0.2 & 3.2 & 14.5 \\
Lsed6 & 0.9 & 1.4 & 1.1 & 1.2 & 0.5 & 1.3 & 2.5 \\
Lsed5 & 0.8 & 0.7 & 1.2 & 1.6 & 0.4 & 2.0 & 5.8 \\
Lsed3 & 1.0 & 0.6 & 0.7 & 0.7 & 1.5 & 21.1 & 14.1 \\
Lsed2 & 1.0 & 0.8 & 1.4 & 1.0 & 0.8 & 9.0 & 11.9 \\
Lsed1 & 1.0 & 0.5 & 1.6 & 0.8 & 1.3 & 8.6 & 6.4 \\
Lsol4a & & & & & 0.3 & 1.4 & 4.5 \\
Lsol4b & & & & & 0.2 & 1.4 & 6.6 \\
Average & 1.0 & 0.7 & 1.2 & 1.1 & 0.8 & 7.5 & 9.2 \\
Sd & 0.1 & 0.3 & 0.3 & 0.3 & 0.5 & 6.8 & 4.5 \\
Dsed2 & 1.0 & 0.6 & 0.9 & 1.2 & 1.6 & 8.2 & 5.1 \\
Dsed3 & 1.0 & 0.8 & 1.2 & 1.0 & 2.2 & 5.9 & 2.7 \\
Dsed4 & 1.0 & 0.3 & 0.3 & 0.3 & 12.8 & 29.5 & 2.3 \\
Dsed5 & 0.9 & 0.6 & 0.5 & 0.7 & 5.4 & 11.1 & 2.1 \\
Dsed1 & 0.9 & 0.6 & 1.0 & 0.7 & 1.5 & 6.7 & 4.6 \\
Average & 1.0 & 0.6 & 0.8 & 0.8 & 4.7 & 12.3 & 3.3 \\
Sd & 0.0 & 0.2 & 0.4 & 0.3 & 4.3 & 8.8 & 1.3 \\
\hline & & & & & & & \\
\hline
\end{tabular}


Establishing a criterion for deciding what the natural radioactive background is, and what are hot spots (natural high concentration values) and areas with enhanced (modified) radioactive background is not of easy consensus when one deals with naturally occurring radionuclides. However, based on the present data set it is suggested that sites of natural radioactive background in this region are those with ${ }^{40} \mathrm{~K} /{ }^{232} \mathrm{Th}<15$ and ${ }^{238} \mathrm{U} /{ }^{232} \mathrm{Th}<10$ (Figure 4 ). The outliers, i.e., sampling points above typical background concentrations are thus one point in Luilu basin, Lsed3, and two points in the Dilala basin, Dsed4 and Dsed5 (Table 3) and these were also the outliers in probability data plots (not shown).

Radionuclide ratios calculated for several radionuclide pairs are shown in $\mathrm{Ta}$ ble 3. For the purpose of this discussion, the results for primordial radionuclides in soil were grouped and averaged with sediments as soil samples of the Luilu river basin were similar to radionuclide concentrations in sediments,

In Table 3, the activity concentration ratios of uranium daughters with the parent radionuclide, i.e., ${ }^{234} \mathrm{U} /{ }^{238} \mathrm{U},{ }^{230} \mathrm{Th} /{ }^{238} \mathrm{U},{ }^{226} \mathrm{Ra} /{ }^{238} \mathrm{U},{ }^{210} \mathrm{~Pb} /{ }^{238} \mathrm{U}$, in sediment samples give information about radioelement behavior in the aquatic environment. The ${ }^{234} \mathrm{U} /{ }^{238} \mathrm{U}$ ratios in sediments were around 1 which indicate near secular radioactive equilibrium. On the other hand, the values of other radionuclide ratios, although fluctuating, were consistently lower than 1 indicating dissolution and removal by river water. This has been described for other rivers. For example, Vigier et al. (2001) reported that radionuclide ratios in sediments from Canadian rivers were found in the ranges of $0.897-0.992$ for ${ }^{234} \mathrm{U} /{ }^{238} \mathrm{U}$, and 0.653 - 1.002 for ${ }^{226} \mathrm{Ra} /{ }^{238} \mathrm{U}$, indicating ${ }^{234} \mathrm{U}$ and ${ }^{226} \mathrm{Ra}$ removal from sediments. This is indicative to the departure from secular radioactive equilibrium due to dissolution/erosion along the river path. In the same report, concentration ratios that included ${ }^{230} \mathrm{Th}$ were even further below unity $\left(0.653-1.002\right.$ for ${ }^{230} \mathrm{Th} /{ }^{238} \mathrm{U}$ and $0.596-1.020$ for ${ }^{226} \mathrm{Ra} /{ }^{230} \mathrm{Th}$ ), which was found now in Congolese rivers as well. Such deviations of concentration ratio values from unity relate to the different solubility of radionuclides. In this case, ${ }^{238} \mathrm{U}$, especially ${ }^{234} \mathrm{U}$ (parent of ${ }^{230} \mathrm{Th}$ ) and ${ }^{226} \mathrm{Ra}$, that were much more soluble when compared with thorium $\left({ }^{230} \mathrm{Th}\right)$, as pointed out by those authors.

In the case of the two Congolese rivers, the radionuclide activity concentration ratios in sediments along the river path also showed that uranium from sediments was gradually dissolved while thorium (nearly insoluble) was retained in the solid phase. But this ratio was occasionally reversed probably due to uranium precipitation. It is likely that geochemical conditions change along the path of these two rivers, with episodes of dissolution followed by reprecipitation of radionuclides, probably in relationship with discharges from mining companies and stirring of sediments by artisanal mining. In such conditions, there is no consistent trend in activity ratios along the river path and the exposure to radiation may vary from one location to the next.

The specific activities of ${ }^{238} \mathrm{U},{ }^{232} \mathrm{Th},{ }^{40} \mathrm{~K}$ and ${ }^{226} \mathrm{Ra}$ determined in this study are compared in Table 4 with results reported in the literature. This comparison highlights that average concentrations in both river basins in the Congo were 
Table 4. Comparison of average activity concentrations $\left(\mathrm{Bq} \cdot \mathrm{kg}^{-1}\right)$ of ${ }^{238} \mathrm{U},{ }^{232} \mathrm{Th},{ }^{226} \mathrm{Ra}$, and ${ }^{40} \mathrm{~K}$ with other countries.

\begin{tabular}{|c|c|c|c|c|c|}
\hline Location & ${ }^{238} \mathrm{U}$ & ${ }^{232} \mathrm{Th}$ & ${ }^{226} \mathrm{Ra}$ & ${ }^{40} \mathrm{~K}$ & References \\
\hline Congo (RDC) Luilu river & $154 \pm 6$ & $28 \pm 2$ & $172 \pm 14$ & $211 \pm 76$ & This study \\
\hline Congo (RDC) Dilala river & $378 \pm 13$ & $30 \pm 6$ & $202 \pm 27$ & $95 \pm 13$ & This study \\
\hline Egypt & $94 \pm 6$ & $78 \pm 5$ & $74 \pm 6$ & $200 \pm 5$ & El-Sadek (2015) \\
\hline Greece & - & 24.5 & 22.6 & 497 & $\begin{array}{l}\text { Papaefthymiou et al. } \\
\text { (2007) }\end{array}$ \\
\hline Nigeria & 16 & 24 & - & 35 & Arogunjo et al. (2004) \\
\hline India & 119 & 285 & - & 1646 & Rajesh and Kerur (2018) \\
\hline Sudan & - & 6.02 & 11.6 & 158.4 & Khatir et al. (1998) \\
\hline $\begin{array}{c}\text { Portugal } \\
\text { (uranium region) }\end{array}$ & $230 \pm 10$ & $226 \pm 19$ & $619 \pm 96$ & - & $\begin{array}{l}\text { Carvalho and Oliveira } \\
\qquad(2007)\end{array}$ \\
\hline
\end{tabular}

higher than values for other regions. Moreover, maximum values measured in sediments of Dilala river are similar to concentrations typically found only in uranium rich areas and in uranium mining waste.

\subsection{Evaluation of Radiological Hazards and Health Effect Indices}

The radiological hazard and health effect indices were calculated for all sampling stations and results are shown in Table 5. The $R a_{E q}$ values varied from 120.4 (Lsed5) to $376.2 \mathrm{~Bq} \cdot \mathrm{kg}^{-1}$ (Lsed1). It is noteworthy that $R a_{E q}$ values at all sampling sites were below the world average level of $370 \mathrm{~Bq} \cdot \mathrm{kg}^{-1}$ (UNSCEAR, 2000). The ODRA values were ranged between 50 (Lsed5) and $472.6 \mathrm{nGy} \cdot \mathrm{h}^{-1}$ (Dsed4) with an average value of $121.1 \mathrm{nGy} \cdot \mathrm{h}^{-1}$, which was two times higher than the world average value of $59 \mathrm{nGy} \cdot \mathrm{h}^{-1}$ (UNSCEAR, 2000). The calculated values of AEDE varied from 0.06 (Lsed5) to $0.58 \mathrm{mSv} \cdot \mathrm{y}^{-1}$ (Dsed4). The average level $\left(0.2 \mathrm{mSv} \cdot \mathrm{y}^{-1}\right)$ of AEDE values was 2.9 times higher than the world average of $0.07 \mathrm{mSv} \cdot \mathrm{y}^{-1}$ (UNSCEAR, 2000; UNSCEAR, 2010). The cancer risk parameter (ELCR) values ranged from 0.21 (Lsed5) to 2.03 (Dsed4), and the average value of 0.6 for all sampling sites was three orders of magnitude higher than the world mean level of 0.00029 (UNSCEAR, 2000; UNSCEAR, 2010). The hazard index $H_{e x}$ and $H_{i n}$ values ranged between 0.30 (Lsed5) to 2.77 (Dsed4) and between 0.51 (Lsed5) to 1.91 (Lsed1), respectively. In general, the average values of $H_{e x}$ and $H_{i n}$ were lower than the recommended value of 1, except for sites Dsed4, Dsed5 and Lsed3 for $\mathrm{H}_{\mathrm{ex}}$ and sites Lsed2, Lsed3, Dsed1, Dsed3and Dsed4, $H_{e x}$ and $H_{i n}$. It should be noted that the highest values of $R a_{E q}$, ODRA, AEDE, ELCR and $H_{e x}$ correspond consistently to the sampling sites Dsed4 and Dsed3, where artisanal miners carry out their activities (Table 1). Other sites, such as Lsed3, were occasionally high for some parameters but not consistently to all or at least the majority of them. Therefore, radiological hazards and the risk of health effects on the riverine population were consistently higher in the Dilala river basin in comparison with Luilu river. Although this is primarily due to the natural occurrence of uranium and uranium daughters, the artisanal mining activities at these sites increased 
the exposure to radiation and contributed to the dispersion of radionuclides in the river system.

\subsection{Correlation between Parameters}

In order to determine the relationships and strength of association between pairs of variables, the Spearman rank order correlation was calculated. The results are shown in Table 6.

Table 5. Radium equivalent activity index $\left(R a_{E q}\right)$, outdoor gamma absorbed dose rate (ODRA), annual effective dose equivalent $\left(\mathrm{AEDE}_{\text {outdoor }}\right.$ ), excess lifetime cancer risk (ELCR), and hazard indices $\left(H_{e x}\right.$ and $\left.H_{i n}\right)$ for the investigated samples.

\begin{tabular}{|c|c|c|c|c|c|c|}
\hline Sample label & $\begin{array}{c}R a_{E q} \\
\left(\mathrm{~Bq} \cdot \mathrm{kg}^{-1}\right)\end{array}$ & $\begin{array}{c}\text { ODRA } \\
\left(\mathrm{nGy} \cdot \mathrm{h}^{-1}\right)\end{array}$ & $\begin{array}{c}\text { AEDE } \\
\text { outdoor } \\
\left(\mathrm{mSv} \cdot \mathrm{y}^{-1}\right)\end{array}$ & $\begin{array}{c}\text { ELCR } \\
\text { (unitless) }\end{array}$ & $\begin{array}{c}H_{e x} \\
\text { (unitless) }\end{array}$ & $\begin{array}{c}H_{\text {in }} \\
\text { (unitless) }\end{array}$ \\
\hline Lsed7 & 137.7 & 66.7 & 0.08 & 0.29 & 0.39 & 0.57 \\
\hline Lsed6 & 167.7 & 71.6 & 0.09 & 0.31 & 0.43 & 0.67 \\
\hline Lsed5 & 120.4 & 50.0 & 0.06 & 0.21 & 0.30 & 0.51 \\
\hline Lsed3 & 276.2 & 174.7 & 0.21 & 0.75 & 1.02 & 1.38 \\
\hline Lsed2 & 289.6 & 99.9 & 0.12 & 0.43 & 0.58 & 1.44 \\
\hline Lsed 1 & 376.2 & 116.6 & 0.14 & 0.50 & 0.68 & 1.91 \\
\hline Lsol4a & 158.6 & 60.5 & 0.07 & 0.26 & 0.36 & 0.66 \\
\hline Lsol4b & 156.3 & 67.8 & 0.08 & 0.29 & 0.40 & 0.61 \\
\hline Dsed2 & 212.9 & 106.1 & 0.13 & 0.46 & 0.62 & 1.04 \\
\hline Dsed3 & 304.2 & 120.7 & 0.15 & 0.52 & 0.71 & 1.49 \\
\hline Dsed4 & 295.0 & 472.6 & 0.58 & 2.03 & 2.77 & 1.45 \\
\hline Dsed5 & 205.7 & 174.6 & 0.21 & 0.75 & 1.03 & 0.98 \\
\hline Dsed1 & 243.0 & 109.1 & 0.13 & 0.47 & 0.64 & 1.18 \\
\hline Average & 214.0 & 121.1 & 0.2 & 0.6 & 0.5 & 0.7 \\
\hline Minimum & 120.4 & 50.0 & 0.06 & 0.21 & 0.30 & 0.51 \\
\hline Maximum & 376.2 & 472.6 & 0.58 & 2.03 & 2.77 & 1.91 \\
\hline Reference value & 370 & 59 & 0.07 & 0.00029 & $\leq 1$ & $\leq 1$ \\
\hline
\end{tabular}

Table 6. Spearman rank order correlation between radiological variables in soil and sediments samples.

\begin{tabular}{|c|c|c|c|c|c|c|c|c|c|}
\hline Variables & ${ }^{226} \mathrm{Ra}$ & ${ }^{232} \mathrm{Th}$ & ${ }^{40} \mathrm{~K}$ & $R a_{E q}$ & ODRA & $\begin{array}{c}\text { AEDE } \\
\text { outdoor }\end{array}$ & ELCR & $H_{e x}$ & $H_{i n}$ \\
\hline${ }^{238} \mathrm{U}$ & 0.718 & -0.353 & -0.556 & 0.757 & 0.977 & 0.986 & 0.982 & 0.971 & 0.757 \\
\hline${ }^{226} \mathrm{Ra}$ & & -0.388 & -0.357 & 0.984 & 0.720 & 0.714 & 0.716 & 0.703 & 0.984 \\
\hline${ }^{232} \mathrm{Th}$ & & & -0.212 & -0.300 & -0.234 & -0.244 & -0.234 & -0.195 & -0.300 \\
\hline${ }^{40} \mathrm{~K}$ & & & & -0.429 & -0.604 & -0.632 & -0.628 & -0.654 & -0.429 \\
\hline
\end{tabular}

Correlation coefficients were calculated using the log value of the parameter contents to normalize their distribution ( $\mathrm{n}=5$, statistically significant coefficients $(p<0.05)$ are in bold). 
A positive correlation, significant at $p<0.05$, was observed between ${ }^{238} \mathrm{U}$ and ${ }^{226} \mathrm{Ra}$, which is not surprising because both radionuclides are members of the same radioactive decay series (uranium series) and thus originate from the same geological sources.

The negative correlation between ${ }^{238} \mathrm{U}$ and ${ }^{232} \mathrm{Th}$, between ${ }^{238} \mathrm{U}$ and ${ }^{40} \mathrm{~K}$, and between ${ }^{226} \mathrm{Ra}$ and ${ }^{40} \mathrm{~K}$ can be explained by the fact that radionuclides of each pair are not from the same radioactive decay series and do not originate from the same geological sources. Furthermore, they are likely to be transferred through different pathways in the environment, i.e., the negative correlation suggests that they are not associated in their environmental cycling.

Positive and statistically significant correlation coefficients $(\mathrm{p}<0.05)$ were observed also between ${ }^{238} \mathrm{U}$ and ${ }^{226} \mathrm{Ra}$ concentrations with all radiological indices ( $R a_{E q}$, ODRA, AEDE, ELCR, $H_{e x}, H_{i n}$ ). These correlations follow the very strong contribution from these two radionuclides to the radiological parameter indices. Indeed, it is clear from the data that these two radionuclides are the main contributors to the gamma dose at all sampling sites. Despite its contribution to the external radiation dose, ${ }^{40} \mathrm{~K}$ displayed negative correlation with the radiological hazard parameters. The radioactive potassium is not considered a radiological threat through ingestion due to the homeostatic control of potassium concentration in the organism.

\section{Conclusion and Research Outlook}

The activity concentrations and environmental distribution of a selection of key natural radionuclides $\left({ }^{238} \mathrm{U},{ }^{235} \mathrm{U},{ }^{234} \mathrm{U},{ }^{232} \mathrm{Th},{ }^{230} \mathrm{Th},{ }^{228} \mathrm{Ra},{ }^{226} \mathrm{Ra},{ }^{210} \mathrm{~Pb}\right.$, and $\left.{ }^{40} \mathrm{~K}\right)$ were determined using gamma-ray and alpha-particle spectrometry for the analysis of soil and sediment samples from Luilu and Dilala river basins, at the Kolwezi district in the Democratic Republic of the Congo. In general, the concentrations of the four primordial radionuclides ${ }^{238} \mathrm{U},{ }^{232} \mathrm{Th},{ }^{226} \mathrm{Ra}$ and ${ }^{40} \mathrm{~K}$ were within the worldwide average concentrations reported by UNSCEAR. Furthermore, the highest concentration values of these radionuclides, well above the average natural background, were determined at locations impacted by artisanal mining activities, confirming the co-occurrence of uranium with non-radioactive metals targeted by the miners.

The average ODRA, AEDE and ELCR calculated showed higher values than the world average level (reference level) for each parameter. In these river basins, the sampling sites Dsed3, Dsed4 and Lsed1 where artisanal mining (mineral washing or sediment collection from the riverbed by artisanal miners) was carried out, displayed the highest activity concentrations values for ${ }^{238} \mathrm{U},{ }^{235} \mathrm{U},{ }^{234} \mathrm{U}$, ${ }^{230} \mathrm{Th},{ }^{226} \mathrm{Ra}$, and ${ }^{210} \mathrm{~Pb}$. Health risks from radiation exposure, assessed through the ELCR were generally elevated, especially in the Dilala basin, when compared with the reference value.

The results from this assessment of radiological hazards and health risks confirmed that the artisanal mining activity in this region, although targeting 
non-nuclear minerals, enhanced radiation exposure and radiological hazards to riverine populations. As the population engaged in artisanal mining is much wider in the country, a full assessment of radiation exposure should be carried out in other provinces also, and the results should be used to design a suitable radiation protection policy. This study is the first in this field for the DRC and it is a starting point for use in future monitoring and investigations on environmental radioactivity aiming to enhance the radiation protection of population.

\section{Statement on Consent}

Photos were taken with permission and their use was consented by people portrayed.

\section{Acknowledgements}

The analytical work was performed in the facilities of the Radiological Protection and Safety Laboratory of the Instituto Superior Técnico/ Campus Tecnológico e Nuclear of the University of Lisbon, Portugal.

\section{Conflicts of Interest}

The authors declare no conflicts of interest regarding the publication of this paper.

\section{References}

Agbalagba, E. O., \& Onoja, R. A. (2011). Evaluation of Natural Radioactivity in Soil, Sediment and Water Samples of Niger Delta (Biseni) Flood Plain Lakes, Nigeria. Journal of Environmental Radioactivity, 102, 667-671. https://doi.org/10.1016/j.jenvrad.2011.03.002

Arogunjo, A. M., Farai, I. P., \& Fuwape, I. A. (2004). Dose Rate Assessment of Terrestrial Gamma Radiation in the Delta Region of Nigeria. Radiation Protection Dosimetry, 108, 73-77. https://doi.org/10.1093/rpd/nch010

Atibu, E. K., Devarajan, N., Laffite, A., Giuliani, G., Salumu, J. A., Muteb, R. C., Mulaji, C. K., Otamonga, J.-P., Elongo, V., Mpiana, P. T., \& Poté, J. (2016). Assessment of Trace Metal and Rare Earth Elements Contamination in Rivers around Abandoned and Active Mine Areas. The Case of Lubumbashi River and Tshamilemba Canal, Katanga, Democratic Republic of the Congo. Geochemistry, 76, 353-362.

https://doi.org/10.1016/j.chemer.2016.08.004

Atibu, E. K., Devarajan, N., Thevenon, F., Mwanamoki, P. M., Tshibanda, J. B., Mpiana, P. T., Prabakar, K., Mubedi, J. I., Wildi, W., \& Poté, J. (2013). Concentration of Metals in Surface Water and Sediment of Luilu and Musonoie Rivers, Kolwezi-Katanga, Democratic Republic of Congo. Applied Geochemistry, 39, 26-32. https://doi.org/10.1016/j.apgeochem.2013.09.021

Atibu, E. K., Gregory, G., Mulaji, C. K., Otamonga, J. P., Elonga, V., Mpiana, P. T., \& Poté, J. (2018). Impact Assessment of an Area Contaminated by Abandoned Mine: Case of the Dilala, Mpingiri and Luilu Rivers, District of Kolwezi, Democratic Republic of the Congo. Chemosphere, 191, 1008-1020. https://doi.org/10.1016/j.chemosphere.2017.10.052

Beretka, J., \& Mathew, P.J. (1985). Natural Radioactivity of Australian Building Materials, 
Industrial Wastes and By-Products. Health Physics, 48, 87-95.

https://doi.org/10.1097/00004032-198501000-00007

Carvalho, F. P. (1995). ${ }^{210} \mathrm{~Pb}$ and ${ }^{210} \mathrm{Po}$ in Sediments and Suspended Matter in the Tagus Estuary, Portugal. Local Enhancement of Natural Levels by Wastes from Phosphate Ore Processing Industry. Science of the Total Environment, 159, 201-214. https://doi.org/10.1016/0048-9697(95)04332-U

Carvalho, F. P., \& Oliveira, J. M. (2007). Alpha Emitters from Uranium Mining in the Environment. Journal of Radioanalytical and Nuclear Chemistry, 274, 167-174. https://doi.org/10.1007/s10967-006-6914-3

Carvalho, F. P., \& Oliveira, J. M. (2009). Performance of Alpha Spectrometry in the Analysis of Uranium Isotopes in Environmental and Nuclear Materials. Journal of Radioanalytical and Nuclear Chemistry, 281, Article No. 591.

https://doi.org/10.1007/s10967-009-0046-2

Carvalho, F. P., Madruga, M. J., Reis, M. C., Alves, J. G., Oliveira, J. M., Gouveia, J., \& Silva, L. (2007). Radioactivity in the Environment around Past Radium and Uranium Mining Sites of Portugal. Journal of Environmental Radioactivity, 96, 39-46. https://doi.org/10.1016/j.jenvrad.2007.01.016

Cheyns, K., Banza Lubaba Nkulu, C., Ngombe, L. K., Asosa, J. N., Haufroid, V., De Putter, T., Nawrot, T., Kimpanga, C. M., Numbi, O. L., Ilunga, B. K., Nemery, B., \& Smolders, E. (2014). Pathways of Human Exposure to Cobalt in Katanga, a Mining Area of the D.R. Congo. Science of the Total Environment, 490, 313-321. https://doi.org/10.1016/j.scitotenv.2014.05.014

Choppin, G. R., liljenzin J. O., \& Rydberg, J. (1995). Radiochemistry and Nuclear Chemistry (2nd ed.). Oxford: Butterworth-Heinnemann.

Eisenbud, M., \& Gesell, T. (1997). Environmental Radioactivity from Natural, Industrial and Military Sources (4th ed.). London: Academic Press.

El-Sadek, M. A. (2015). Assessment of Radiological Indices of Soil Samples from Northern Egypt through the Measurement of the Activity Concentrations of Natural Radionuclides. International Journal of Environmental Science and Toxicology Research, 3, 144-153.

Fisher, D. R., \& Fahey, F. H. (2017). Appropriate Use of Effective Dose in Radiation Protection and Risk Assessment. Health Physics, 113, 102-109. https://doi.org/10.1097/HP.0000000000000674

Grujensch, C. (1978). Quelques observations sur la position stratigraphique de la "Série des mines” au Shaba 1. Annales de la Société Géologique de Belgique, 101, 1-11.

ICRP (International Commission on Radiological Protection) (1991). Recommendations of the International Commission on Radiological Protection. Annals of the ICRP, 21, ICRP Publication 60, 2-4.

Issa, S., Uosif, M., \& Elsaman, R. (2013). Gamma Radioactivity Measurements in Nile River Sediment Samples. Turkish Journal of Engineering and Environmental Sciences, 37, 109-122.

Khatir, A. S., Ahmed, M. M. O., El-Khangi, F. A., El-Nigumi, Y. O., \& Holm E. (1998). Radioactivity Levels in the Red Sea Coastal Environment of Sudan. Marine Pollution Bulletin, 36, 19-26. https://doi.org/10.1016/S0025-326X(98)90025-X

Malaisse, F., Brooks, R. R., \& Baker, A. J. M. (1994). Diversity of Vegetation Communities in Relation to Soil Heavy Metal Content at the Shinkolobwe Copper/Cobalt/Uranium Mineralization, upper Shaba, Zaire. Belgian Journal of Botany, 127, 3-16.

Mees, F., Masalehdani, M. N. N., De Putter, T., D’Hollander, C., Van Biezen, E., Mujinya, 
B. B., Potdevin, J. L., \& Van Ranst, E. (2013). Concentrations and Forms of Heavy Metals around Two Ore Processing Sites in Katanga, Democratic Republic of Congo. Jour nal of African Earth Sciences, 77, 22-30. https://doi.org/10.1016/j.jafrearsci.2012.09.008

Michalik, B. (2017). NORM Contaminated Area Identification Using Radionuclides Activity Concentration Pattern in a Soil Profile. Journal of Environmental Radioactivity, 173, 102-111.

Mustapha, A. O., Mbuzukongira, P., \& Mangala, M. J. (2007). Occupational Radiation Exposures of Artisans Mining Columbite-Tantalite in the Eastern Democratic Republic of Congo. Journal of Radiological Protection, 27, 187-195. https://doi.org/10.1088/0952-4746/27/2/005

Oliveira, J. M., \& Carvalho, F. P. (2006). A Sequential Extraction Procedure for Determination of Uranium, Thorium, Radium, Lead and Polonium Radionuclides by Alpha Spectrometry in Environmental Samples. Czechoslovak Journal of Physics, 56, Article No. D545. https://doi.org/10.1007/s10582-006-1064-8

Papaefthymiou, H., Papatheodorou, G., Moustakli, A., Christodoulou, D., \& Geraga, M. (2007). Natural Radionuclides and ${ }^{137}$ Cs Distributions and their Relationship with Sedimentological Processes in Patras Harbour, Greece. Journal of Environmental Radioactivity, 94, 55-74. https://doi.org/10.1016/j.jenvrad.2006.12.014

Pham, M. K., Benmansour, M., Carvalho, F. P., Chamizo, E., Degering, D., \& Engelerf, C. (2014). Certified Reference Material IAEA-446 for Radionuclides in Baltic Sea Seaweed. Applied Radiation and Isotopes, 87, 468-474. https://doi.org/10.1016/j.apradiso.2013.11.013

Pham, M. K., vanBeek, P., Carvalho, F. P., Chamizo, E., Degering, D., Engeler, C., Gascó, C. et al. (2016). Certified Reference Materials for Radionuclides in Bikini Atoll Sediment (IAEA-410) and Pacific Ocean Sediment (IAEA-412). Applied Radiation and Isotopes, 109, 101-104. https://doi.org/10.1016/j.apradiso.2015.11.041

Povinec, P. P., Pham, M., Barci-Funel, G., Bojanowski, R., Boshkova, T., Burnett W., \& Carvalho, F. P. et al. (2007). Reference Material for Radionuclides in Sediment, IAEA-384 (Fangataufa Lagoon Sediment). Journal of Radioanalytical and Nuclear Chemistry, 273, 383-393. https://doi.org/10.1007/s10967-007-6898-4

Rahman, S., \& Faheem, M. (2008). Natural Radioactivity Measurements in Pakistan an Overview. Journal of Radiological Protection, 28, 443-452.

Rajesh, S., \& Kerur, B. R. (2018). Assessment of Natural Radioactivity Levels Due to ${ }^{238} \mathrm{U}$, ${ }^{232} \mathrm{Th}$ and ${ }^{40} \mathrm{~K}$ in the Soil Samples of Raichur District, Karnataka, India. Radiation Protection and Environment 41, 51-54. https://doi.org/10.4103/rpe.RPE_16_18

Ramasamy, V., Suresh, G., Meenakshisundaram, V., \& Ponnusamy, V. (2011). Horizontal and Vertical Characterization of Radionuclides and Minerals in River Sediments. Applied Radiation and Isotopes, 69, 184-195.

https://doi.org/10.1016/j.apradiso.2010.07.020

Suresh Ghandhi, M., Ravisanker, R., Rajalakshmi, A., Sivakumar, S., Chandrasekaran, A., \& Pream Anand, D. (2014). Measurements of Natural Gamma Radiation in Beach Sediments of North East Coast of Tamilnadu, India by Gamma Ray Spectrometry with Multivariate Statistical Approach. Journal of Radiation Research and Applied Sciences, 7, 7-17. https://doi.org/10.1016/j.jrras.2013.11.001

Taqi, A. H., Shaker, A. M., \& Battawy, A. A. (2018). Natural Radioactivity Assessment in Soil Samples from Kirkuk City of Iraq Using HPGe Detector. International Journal of Radiation Research, 16, 455-463.

Taskin, H., Karavus, M., Ay, P., Topuzoglu, A., Hidiroglu, S., \& Karahan, G. (2009). The Investigation of Radionuclide Concentrations in Soil and Lifetime Cancer Risk Due to 
Gamma Radioactivity in Zonguldak, Turkey. Journal of Environmental Radioactivity, 100, 49-53. https://doi.org/10.1016/j.jenvrad.2008.10.012

UNSCEAR (United Nations Scientific Committee on the Effects of Atomic Radiation) (2010). Sources and Effects of Ionizing Radiation. New York, NY: United Nations.

UNSCEAR (United Nations Scientific Committee on the Effects of Atomic Radiation) (2000). Sources and Effects of Ionizing Radiation. New York, NY: United Nations.

UNSCEAR (United Nations Scientific Committee on the Effects of Atomic Radiation) (1993). Sources and Effects of Ionizing Radiation. Report to the General Assembly with Annexes. New York, NY: United Nations.

Vigier, N., Bourdon, B., Turner S., \& Allègre, C. J. (2001). Erosion Timescales Derived from U-Decay Series Measurements in Rivers. Earth and Planetary Science Letter, 193, 549-563. https://doi.org/10.1016/S0012-821X(01)00510-6 